\title{
Honey Productivity and Marketing in Ethiopia: A Review
}

\author{
BETELA BEYENE BARENA \\ Department of Agribusiness and Value Chain Management, College of Agriculture, Wolaita Sodo \\ University,P.O.Box. 138
}

\begin{abstract}
Beekeeping has been contributing to the household income, employment, poverty alleviation and national economy through export. Ethiopia is the leading honey and beeswax producer in Africa. Honey and beeswax products are part of the apiculture market, which encompasses a wide range of products, from primary commodities to highly processed, high value consumer goods. However, various researchers revealed that the productivity, quality and marketing of honey and beeswax should be improved. This review paper also tried to address productivity and marketing volume of honey; and constraints and opportunities of honey production and marketing in Ethiopia. Income from the sector is minimal, primarily due to low productivity and poor quality, but also because of limited market access, which forces producers to sell locally at low prices. Honey production is frequently promoted as a pro-poor income generation activity as it is accessible to many members of a rural community, has low start-up costs and requires little land or labor. Factors have kept Ethiopian honey production from reaching its full market potential are backward technology for honey production; which includes traditional beehives and results in low quantity and poor quality of honey produced, lack of financial resources (such as access to loans) for beekeepers to obtain modern beehives. Therefore, the government policy dimension on commercialization of agriculture and major emphasis on beekeeping subsector stimulates the intensive involvement of small scale farmers as well as traders in honey production, productivity, processing and marketing.
\end{abstract}

Keywords: Honey, Productivity, pro-poor, Nutritional value

DOI: $10.7176 / \mathrm{DCS} / 9-5-04$

Publication date:May $31^{\text {st }} 2019$

\section{INTRODUCTION}

\subsection{Back ground of the Study}

Establishing Ethiopia's competitive advantage in honey and beeswax production to develop a substantial export trade is an important goal of the Growth and Transformation Plan (MoFED, 2010). Increasing productivity and incomes in the very large and small-scale commercial apiculture sector is part of the long term vision. Ethiopia produces around $23.6 \%$ and $2.1 \%$ of the total Africa and World's honey, respectively. Ethiopia is one of the top 10 producers of honey in the world, and it is the largest one in Africa (AGP-AMD, 2012).

The total volume of honey production in 2011 was estimated to be 39.89 million kilograms $(\mathrm{kg})$ (CSA, 2012). These non farming business activities have the potential to provide a wide range of economic contributions. Honey and beeswax products are part of the apiculture market, which encompasses a wide range of products, from primary commodities to highly processed, high value consumer goods (SNV, 2006).

Currently, the majority of honey produced (about 70 percent of the 90 to 95 percent designated for sale) is sold to tej houses. The remaining portion is marketed as table honey for general consumption (Tadesse and Phillips 2007). Income from the sector is minimal, primarily due to low productivity and poor quality, but also because of limited market access, which forces producers to sell locally at low prices. Honey production is frequently promoted as a pro-poor income generation activity as it is accessible to many members of a rural community, has low start-up costs and requires little land or labor (MoARD, 2007).

From traditional hives, an average of 5 to $6 \mathrm{~kg}$ of honey could be cropped per hive per year. However, in areas where improved technology has been introduced, yields of 15 to $20 \mathrm{~kg}$ per hive per year have been recorded. In further, the progresses in different aspects of honey production, productivity and marketing have a little reviewed. Yet productivity and poor quality of bee products are the major economic impediments for beekeepers (Nuru, 1999). The honey chain that is more profitable to the beekeeper is not also identified (Amanuel, 2011).

\subsection{Objectives}

* To review production, productivity and marketing volume of honey in Ethiopia

* To understand challenges and opportunities for development of honey production and marketing.

\section{LITRATURE REVIEW}

\subsection{Honey Production, marketing and Consumption -Global overview}

World honey production is estimated to 1.2 million tons (ICT, 2003 in MoARD, 2007). China dominates honey production in the world, accounting for $22 \%$ of world honey production in 2004 and growing nearly 3 times 
faster than the world average (CAP, 2008). In the year 2007, China accounted for about $42 \%$ of the total honey produced by the 10 largest honey producing countries in the world (FAO, 2007). Ethiopia was ranked 10th in honey production in the world. According to (MoARD, 2003) Ethiopia accounts for about 23.58\% of the total African and $2.13 \%$ of the world honey production (FAO, 2007).

Honey production is frequently promoted as a pro-poor income generation activity as it is accessible to many members of a rural community, has low start-up costs and requires little land or labor (MoARD, 2007). According to MoARD (2003), about $10 \%$ of the honey produced in the country is consumed by beekeeping households. The remaining $90 \%$ is sold for income generation and of this amount, it is estimated that $70 \%$ is used for brewing tej and the balance is consumed as table honey. Tej brewers exclusively use crude honey from traditional hives. The final destination for the most of the honey is Addis Ababa and big regional towns located at different parts of the country. In recent times, many table honey processing plants have begun operations and already started buying honey at production areas either directly or through agents and significantly competing with local honey collectors and traders. These companies process and pack honey and market it as table honey, mainly at local supermarkets.

\subsection{Honey Contribution in Ethiopian Economy}

Beekeeping is an important economic activity, with the sector contributing around $\$ 1.6 \mathrm{~m}$ annually to the national economy (MoA, 2008). The production of honey and beeswax provides a secondary source of income for smallholder farmers, who traditionally also grow cereals, pulses, oil seeds, and chillies. The country has more than ten million beehives, the largest number in Africa, and around two million people are involved in the value chain. Ethiopia is Africa's largest producer of both honey and beeswax, and the fourth largest producer of beeswax in the world (Allafrica.com, 2009).

Honey in Ethiopia is generally produced as a cash crop, with yearly sales amounting to 90 to 95 percent of total production (Tadesse and Phillips 2007). The total volume of honey production in Ethiopia in 2007-2011 was $163,257.42$ tons, of which 99.2 percent was consumed domestically and 0.8 percent was exported. The total volume of Ethiopian honey exports in 2007-2011 was 1,297,716 kg, with a total value of US\$4,066,528 (CSA, 2011).

A study conducted by SNV (2005) shows that Oromia regional state produces about $41 \%$ of total national honey production followed by SNNPR and Amhara regions contributing about $22 \%$, and $21 \%$ of the national production respectively. Tigray contributes close to $5 \%$ and all other regions including BGR contribute $11 \%$. Ethiopia's production of honey was between 21,480 and 23,700 tons per annum during the 1998/99 making Ethiopia the leading producer in Africa (SNV, 2005). Since then, the production of honey increased significantly due to introduction of beekeeping technologies and capacity building on beekeeping to assist producers to participate in honey production. The annual honey production of Ethiopia is estimated to be 45,300 metric tons which makes the country rank first honey- producing country in Africa and ninth in the world (FAO, 2010).

Table 1:Honey production and exports versus domestic consumption in Ethiopia

\begin{tabular}{llll}
\hline Year & $\begin{array}{l}\text { Total Production Volume (in } \\
\mathrm{Kg} \text { ) }\end{array}$ & $\begin{array}{l}\text { Total Export Volume } \\
\text { (in kg) }\end{array}$ & $\begin{array}{l}\text { Total } \\
\text { Consumption (in kg) }\end{array}$ \\
\hline $\mathbf{2 0 0 7 - 2 0 0 8}$ & $42,180,346$ & 219,889 & $41,960,457$ \\
$\mathbf{2 0 0 7 - 2 0 0 9}$ & $39,660,647$ & 143,412 & $39,517,235$ \\
$\mathbf{2 0 0 7 - 2 0 1 0}$ & $41,524,967$ & 414,115 & $41,110,852$ \\
$\mathbf{2 0 0 7 - 2 0 1 1}$ & $39,891,460$ & 520,301 & $39,371,159$ \\
Total 2007-2011 & $\mathbf{1 6 3 , 2 5 7 , 4 2 0}$ & $\mathbf{1 , 2 9 7 , 7 1 7}$ & $\mathbf{1 6 1 , 9 5 9 , 7 0 3}$ \\
\hline
\end{tabular}

Source: (CSA, 2011)

In 2005 E.C. production year, Ethiopia produced 39,000; 4,300 metric tons of honey and beeswax respectively. The problem with all these traditional hives is that they engender low output; in Ethiopia, for example, there were an estimated 4.55 million hives in 2005 (CSA, 2006) which, based on FAO, 2005 data for National production, is equivalent to $8.85 \mathrm{~kg}$ honey and $0.95 \mathrm{~kg}$ wax perhive per year, although better beekeepers using long hives can achieve $15 \mathrm{~kg}$ per hive per year in more favorable areas. 
Table 2: Production of honey and beeswax in Africa in Metric tones

\begin{tabular}{ccc}
\hline Country & Honey & Beeswax \\
\hline Angola & 23,000 & 2,000 \\
Burundi & 240 & 45 \\
Cameroon & 3,000 & 287 \\
Central A.R & 13,000 & 690 \\
Chad & 9600 & 0 \\
Ethiopia & 39,000 & 4,300 \\
Guinea & 600 & 0 \\
Guinea-Bissau & 65 & 100 \\
Kenya & 21,000 & 2,400 \\
Madagascar & & 390
\end{tabular}

Source: FAOstaticallydata,2005

\subsection{Honey processing}

Many tropical countries have successfully processed and marketed crude honeys using producers, cooperatives and small-scale processors. The inferior quality of honey comes from the only mishandling of the product starting from harvesting through storage to marketing (Crane, E. 1990). Proper temperature and control and heating time are a most important factor in honey processing activity. Excessive heat can have detrimental effects on the nutritional value of honey. Honey should be processed as soon as possible after removal from the hive. Honey processing is a sticky operation, in which time and patience are required to achieve the best results.

\subsection{Honey marketing and exporting in Ethiopia}

Ethiopia has a strong domestic honey market. The 810 tonnes of honey in the current export plan for 2012 is only about $1.5 \%$ of the estimated 53.7 thousand tonnes/year currently produced (MoARD, 2012). The rest of the honey produced is consumed locally and the local market is growing both for table honey and honey wine (Tej). Illegal cross boundary trade also has a reasonable share of the honey estimated to be available for the local market. According to Legesse (2014) the whole domestic honey market lacks proper structure and legality. It is of lengthy chain of actors that widens the access of producers to bigger and better paying markets. So, the beekeepers complain the business as not rewarding and even lacking market for their product, while the consumers see the ever increasing price of honey as unfair.

The total volume of Ethiopian honey exports in 2007-2011 was $1,297,716 \mathrm{~kg}$, with a total value of US\$4,066,528. Sudan was the single biggest importer of Ethiopian honey in terms of volume and monetary value. Although the volume of honey exported increases slightly when the totals for 2007 and 2011 are compared, Ethiopia's honey exports are still very low relative to Ethiopia's total honey production (Mikhail et al., 2012).

According to Assefa (2011), domestic honey consumption is increasing due to highly increasing demand for tej, which increased consumption of processed table honey in most urban areas and increased demand for honey in the local industries. Almost all honey that is currently produced in Ethiopia; about 98 percent of the total yearly production is consumed in the domestic market, with only about 2 percent of the total yearly production being exported (USAID, 2012). According to (Mo A, 2003), honey is considered as cash crop and only about $10 \%$ of the honey produced in the country is consumed by the beekeeping households. The remaining $90 \%$ is sold for income generation (Hartmann, I., 2004).

\subsection{Constraints and Opportunities of Honey Production and Marketing}

Factors have kept Ethiopian honey production from reaching its full market potential are backward technology for honey production; which includes traditional beehives and results in low quantity and poor quality of honey produced, lack of financial resources (such as access to loans) for beekeepers to obtain modern beehives and other tools necessary to increase honey production, supply-related barriers to properly managing modern beehives and lack of proper training regarding efficient management of a modern-style apiary. Additional barriers include the disappearance of bee-foraging areas due to crop intensification and the growing use of agrochemicals; extreme weather conditions in some parts of Ethiopia (droughts); poor transportation 
infrastructure; weak knowledge of proper storage techniques (at the farm and local honey collectors'/traders' levels); problems with packaging, especially at the processors' level (e.g., difficulty obtaining a reliable supply of glass jars); weak access to profitable export markets due to low productivity; limited knowledge of exportmarket requirements; and lack of or weak connections with processors (Oxfam, 2011).

The main challenges that are affecting the promotion and development of honey production and marketing are dependence on traditional and low technology input, poor pre and post harvest management, inadequate extension services and poor marketing infrastructure. Furthermore, lack of smallholders' access to finance contributes to inhibiting the adoption of improved technologies for honey production. Poor quality, limited supply in the face of high local demand entailing higher domestic prices, coupled with the absence of an organized market channels and lack of information have made Ethiopian honey uncompetitive in the international market. In spite of the existing constraints, a few honey processors and exporters have emerged; these have managed to certify their products and are able to penetrate markets in the United States, Europe and the Middle East (SNV, 2009).

\section{SUMMARY, CONCLUSION AND RECOMMENDATIONS}

Ethiopia was ranked 10th in honey production in the world. According to (MoARD, 2003) Ethiopia accounts for about $23.58 \%$ of the total African and $2.13 \%$ of the world honey production (FAO, 2007). Establishing Ethiopia's competitive advantage in honey and beeswax production to develop a substantial export trade is an important goal of the Growth and Transformation Plan. The total volume of honey production in 2011 was estimated to be 39.89 million kilograms (kg) (CSA, 2012). These non farming business activities have the potential to provide a wide range of economic contributions. From traditional hives, an average of 5 to $6 \mathrm{~kg}$ of honey could be cropped per hive per year.

However, in areas where improved technology has been introduced, yields of 15 to $20 \mathrm{~kg}$ per hive per year have been recorded. Beekeeping is an important economic activity, with the sector contributing around $\$ 1.6 \mathrm{~m}$ annually to the national economy (MoA, 2008). The production of honey and beeswax provides a secondary source of income for smallholder farmers, who traditionally also grow cereals, pulses, oil seeds, and chillies. Ethiopia has a strong domestic honey market. The 810 tonnes of honey in the current export plan for 2012 is only about $1.5 \%$ of the estimated 53.7 thousand tonnes/year currently produced (MoARD, 2012). The rest of the honey produced is consumed locally and the local market is growing both for table honey and honey wine (Tej). Illegal cross boundary trade also has a reasonable share of the honey estimated to be available for the local market. According to Legesse (2014) the whole domestic honey market lacks proper structure and legality. Yet productivity and poor quality of bee products are the major economic impediments for beekeepers. Therefore, the government policy dimension on commercialization of agriculture and major emphasis on beekeeping subsector stimulates the intensive involvement of small scale farmers as well as traders in honey production, productivity, processing and marketing in Ethiopia.

\section{REFERENCES}

Allafrica.com (2009) 'Ethiopia: land of wax and honey', April 2009. http://allafrica.com/stories/200904170706.html

Assefa, M., 2011. Pro-poor value chains to make Oromia, Ethiopia. American Journal of Research market more inclusive for the rural poor: Lessons Communication, 2(10): 342-353\} www.usafrom the Ethiopian honey value chain.

Beyene Tadesse and Phillips, D. 2007. Ensuring small-scale producers in Ethiopia to achieve sustainable and fair access to honey markets. Paper prepared for International Development Enterprises (IDE) and Ethiopian Society for Appropriate Technology (ESAT). Addis Ababa, Ethiopia: IDE.

Crane, E. 1990. Bees and beekeeping: science, practice and world resources. Heinnmann Newness, London. Pp614.

CSA, 2006. Statistical Abstract 2005. Central Statistical Agency: Addis Ababa, Ethiopia. Ayalew, K. and Nuru, A. 1988. Moisture content determination of Ethiopian honey. Proc. 4 int. Conf. Apic. trop. Climates, Cairo, 1988: 265-267.

CSA (Central Statistical Authority). 2010/2011. Agricultural sample survey: Report on livestock, poultry and beehives population. Addis Ababa, Ethiopia: CSA.

CSA (2012). Producers' Prices of Agricultural Products at Zone Level 2005-2011.

Danish journals.com. Institute for International Studies, Copenhagen, 31. Tadesse, G. and B. Gebregziabher, 2014. Denmark. pp: $35-50$

Engaging Smallholders in Value Chains, Programme Insights, Oxfam GB. April 2011

FAO (Westlake).2005. Addressing Marketing and Processing Constraints that Inhabit Agri food Exports: A guide for Policy Analysis's and planners.Agricultural Service Bulletin 160.

FAO Stats. (n.d.). Honey Producers Prices 2000-2009. Retrieved July 20-28, 2012, from 
http://faostat.fao.org/site/339/default.aspx.

Hartmann, I., 2004. The management of resources and marginalization in beekeeping Societies of Southwest Ethiopia. Paper submitted to the conference: Bridge Scales and Epistemologies

Mo A.R.D., 2003. Honey and Beeswax marketing and development. In Development, M. O. A. A. R. (Ed.) Plan 2003. Addis Ababa, Ethiopia.

MoARD, 2007. Livestock Development Master Plan Study. Phase I Report - Data Collection and Analysis, Volume N- Apiculture. Addis Ababa, Ethiopia, Ministry of Agriculture and Rural Development

MoARD. 2012. The 5th national monitoring plan for residues in honey from Ethiopia. Addis Ababa, Ethiopia: MoARD.

MoFED. 2010. Growth and Transformation Plan (GTP) 2010/11-2014/15. Addis Ababa, Ethiopia

Ministry of Trade (Ethiopia). Volumes and Values of Honey Export in Years 2007-2011. Retrieved on July 2028,2012

Ministry of Agriculture and Rural Development, Government of Ethiopia, December 2008.

Oxfam (2008) Partner Market Report.

SNV Support to Business Organizations and their Access to Markets (BOAM)-Strategic Intervention Plan on Honey and Bees-Wax Value Chain; Johannes Agonafir (August 2005).

USAID., 2012. Cost-Benefit Analysis of the Honey Value Chain in Ethiopia, Graduation With Resilience To Achieve Sustainable Development - Grad Project Final Report.

Teferi, M.., G. Yirga, T. Hailemichael and S. Amare, 2011. Prospects of beekeeping in the Northern Ethiopian highlands Scientific Research and Essays Vol. 6(29), pp. 6039-6043, Available online at http://www.academicjournals.org/SRE

United States Agency for International Development (USAID). (2012). Agricultural Growth ProgramAgribusiness and Market Development (AGP-AMDe) Project. Submitted by ACDI/VOCA to Contracting Officer's Representative Tewodros Yeshiwork, USAID Ethiopia. 